\title{
Action after Adverse Events in Healthcare: An Integrative Literature Review
}

\author{
Mari Liukka ${ }^{1,2, *(\mathbb{D}}$, Alison Steven ${ }^{3}(\mathbb{D})$, M Flores Vizcaya Moreno ${ }^{4}\left(\mathbb{D}\right.$, Arja M Sara-aho ${ }^{5}$, \\ Jayden Khakurel ${ }^{6}\left(\mathbb{D}\right.$, Pauline Pearson ${ }^{3}$, Hannele Turunen ${ }^{1,7}{ }^{-1}$ and Susanna Tella $1,5(0)$ \\ 1 Department of Nursing Science/Faculty of Health Sciences, University of Eastern Finland, 70211 Kuopio, \\ Finland; hannele.turunen@uef.fi (H.T.); susanna.tella@lab.fi (S.T.) \\ 2 South Karelia Social and Health Care District, 53130 Lappeenranta, Finland \\ 3 Department of Nursing, Midwifery and Health, Northumbria University, Newcastle upon Tyne NE7 7XA, \\ UK; alison.steven@northumbria.ac.uk (A.S.); pauline.pearson@northumbria.ac.uk (P.P.) \\ 4 Faculty of Health Sciences, University of Alicante, 03690 Alicante, Spain; flores.vizcaya@ua.es \\ 5 Faculty of Health Care \& Social Services, LAB University of Applied Sciences, 53850 Lappeenranta, Finland; \\ arja.sara-aho@lab.fi \\ 6 Research Center for Child Psychiatry, University of Turku, 20500 Turku, Finland; Jayden.khakurel@utu.fi \\ 7 Clinical Development, Education and Research Unit of Nursing (CDERUN), Kuopio University Hospital, \\ 70210 Kuopio, Finland \\ * Correspondence: mari.liukka@gmail.com; Tel.: +358-44-791-4871
}

Received: 7 May 2020; Accepted: 24 June 2020; Published: 30 June 2020

\begin{abstract}
Adverse events are common in healthcare. Three types of victims of patient-related adverse events can be identified. The first type includes patients and their families, the second type includes healthcare professionals involved in an adverse event and the third type includes healthcare organisations in which an adverse event occurs. The purpose of this integrative review is to synthesise knowledge, theory and evidence regarding action after adverse events, based on literature published in the last ten years (2009-2018). In the studies critically evaluated $(n=25)$, key themes emerged relating to the first, second and third victim elements. The first victim elements comprise attention to revealing an adverse event, communication after an event, first victim support and complete apology. The second victim elements include second victim support types and services, coping strategies, professional changes after adverse events and learning about adverse event phenomena. The third victim elements consist of organisational action after adverse events, strategy, infrastructure and training and open communication about adverse events. There is a lack of comprehensive models for action after adverse events. This requires understanding of the phenomenon along with ambition to manage adverse events as a whole. When an adverse event is identified and a concern expressed, systematic damage preventing and ameliorating actions should be immediately launched. System-wide development is needed.
\end{abstract}

Keywords: patient safety; adverse events; first victims; second victims; third victims; management

\section{Introduction}

Adverse events (AEs) are inevitable in nursing and healthcare [1,2]. Even where best professional care exists, most treatments or investigations have the potential to cause harm [3]. Although the culture and system of a healthcare organisation (HCO) may be well developed, AEs will happen because of human factors and HCOs being complex adaptive systems, always changing and evolving. Thus, comprehensive preparation is important both to minimise harm to victims and to maintain the functionality of HCOs. In organisations with positive patient safety cultures professionals can speak 
openly about issues and events without fear of blame or punishment. Managers promote safety and reporting of AEs is supported and organisational learning occurs [1].

An $\mathrm{AE}$ is defined as an unintended or unexpected incident which causes harm to a patient and may lead to temporary or permanent disability $[1,4]$. Approximately every tenth patient in hospital suffers such events [5]. A quarter of these events in Europe are healthcare-associated infections; other AE types include medication errors, surgical errors, diagnostic errors, medical device failures or failure to act on test results [6]. Nurses and healthcare professionals often witness or are involved in AEs $[2,7,8]$. In healthcare, AEs can, at worst, cause catastrophic consequences [1]. It is clear that taking action after an AE has occurred is as important as prevention. About half of physicians say that involvement in $\mathrm{AE}$ increases stress in their work [9]. Many of the second victims seek support from family, colleagues or supervisor [10]. About 10\% agree that organisations support them in coping with AEs [9].

Three kinds of victims of AEs can be identified. The "first victims" are conceptualised as patients and their families. Patients can suffer from an AE in two ways: first from direct harm caused and then from the way the event is handled [1]. The "second victims", a concept originally introduced by $\mathrm{Wu}$ [11], are healthcare providers, including physicians, nurses, allied clinicians, support personnel, students and volunteers [12], who have been involved in a patient related AE and subsequently experience emotional or physical distress, thus becoming a victim themselves $[13,14]$. The phenomenon is quite common: the prevalence of second victim suffering is anticipated to be approximately $30 \%$, varying from $10.4 \%$ to $43.3 \%$ [15]. Ninety per cent of healthcare professionals reported suffering at least one physical or psychosocial "second victim" symptom [16]. The "third victims" are healthcare organisations in which the AE occurs [17]. The impact on third victims can also be considerable, as AEs may create an organisational crisis leading to long-term business difficulties [18].

The effects of an AE on first, second and third victims include health-related, functional and economic consequences. These are interrelated and can cause significant costs. Both the first and second victims may suffer emotional and psychological, physical, financial and livelihood consequences [19]. In addition, second victims can face professional consequences, including concerns regarding the performance of their work [12,15,20-22]. Healthcare professionals may also experience difficulties working in an environment where AEs have occurred [23,24]. Consequences for third victims relate to effectiveness [12,19,20], reputation [19,25], legal [20] and economic issues [19]. Hence, these phenomena are crucial aspects to consider after an AE.

Managing the aftermath of AEs well can be assumed to have positive consequences for first and second victims' health, behaviour and economic well-being. Considering HCOs as third victims, but also as responsible for the first and second victims, it is clear that where possible systematic prevention of first and second victim consequences, and appropriate care after an $\mathrm{AE}$ is crucial. Constructive actions after an event can have a positive impact on the safety culture, effectiveness of services and financial situation of the HCOs. In the US, the estimated cost of medical error in 2008 was USD 1 trillion, but patient safety improvements are estimated to have saved USD 28 billion [26]. Strategies to reduce the rate of AEs in the European Union alone could prevent more than 750,000 harm-inflicting medical errors per year. That means over 3.2 million fewer days of hospitalisation, 260,000 fewer incidents of permanent disability and 95,000 fewer deaths per year [27]. The economic consequences of AEs, and of how the events are handled, are therefore not limited to healthcare. For nations, increased absence from work, staff leaving the professions and deaths are examples of extreme consequences of AEs. Actions after AEs can be assumed to have serious short- and long-term, direct and indirect impact on individuals, the economy and society.

The purpose of this integrative review is to synthesise existing knowledge on actions following AEs in HCOs such as hospitals and primary care units. The aim is to identify the underlying elements required for damage preventing and ameliorating actions following AEs in order to provide direction for development and future investigation. The research question is: What are the key elements of action immediately after AEs in HCOs? 


\section{Materials and Methods}

\subsection{Design of the Study}

An integrative review approach was used following Whittemore and Knafl's five stages: (1) the problem was identified; (2) the relevant literature published between 2009 and 2018 was sought; (3) the screened data were evaluated using a 10-item tool; (4) the eligible data were analysed using inductive content analysis; and (5) the findings are presented in tables [28]. In addition, the checklist of the Preferred Reporting Items Systematic Reviews and Meta-analysis (PRISMA) Statement (2009) was used to guide the review [29].

\subsection{Search Strategy}

The databases Scopus, CINAHL, Cochrane and PubMed were searched for relevant articles. Boolean search methods were used to retrieve articles related to action after adverse events in healthcare such follows: "adverse event" AND "disclosure" OR "aftermath", "adverse event" AND "professional' support", "healthcare" AND "second victim", "healthcare" AND "after error".

The search, for example, from Scopus included search terms "adverse event" AND "aftermath" OR "disclosure" with limits "in article, title, keywords", "published 2009 to 2018", "article or review", "English language" and "in journals". Articles were included if they reported on action after AE. Articles focusing on, for example, adverse drug reactions or AE reporting were excluded. Articles about AE reports were excluded when they were only about frequency of reports, or near misses and did not present the whole process from AE to disclosure. Search methods, inclusion and exclusion criteria and search outcomes are presented in Figure 1. Twenty-five research or review papers were found for inclusion in the data evaluation process.

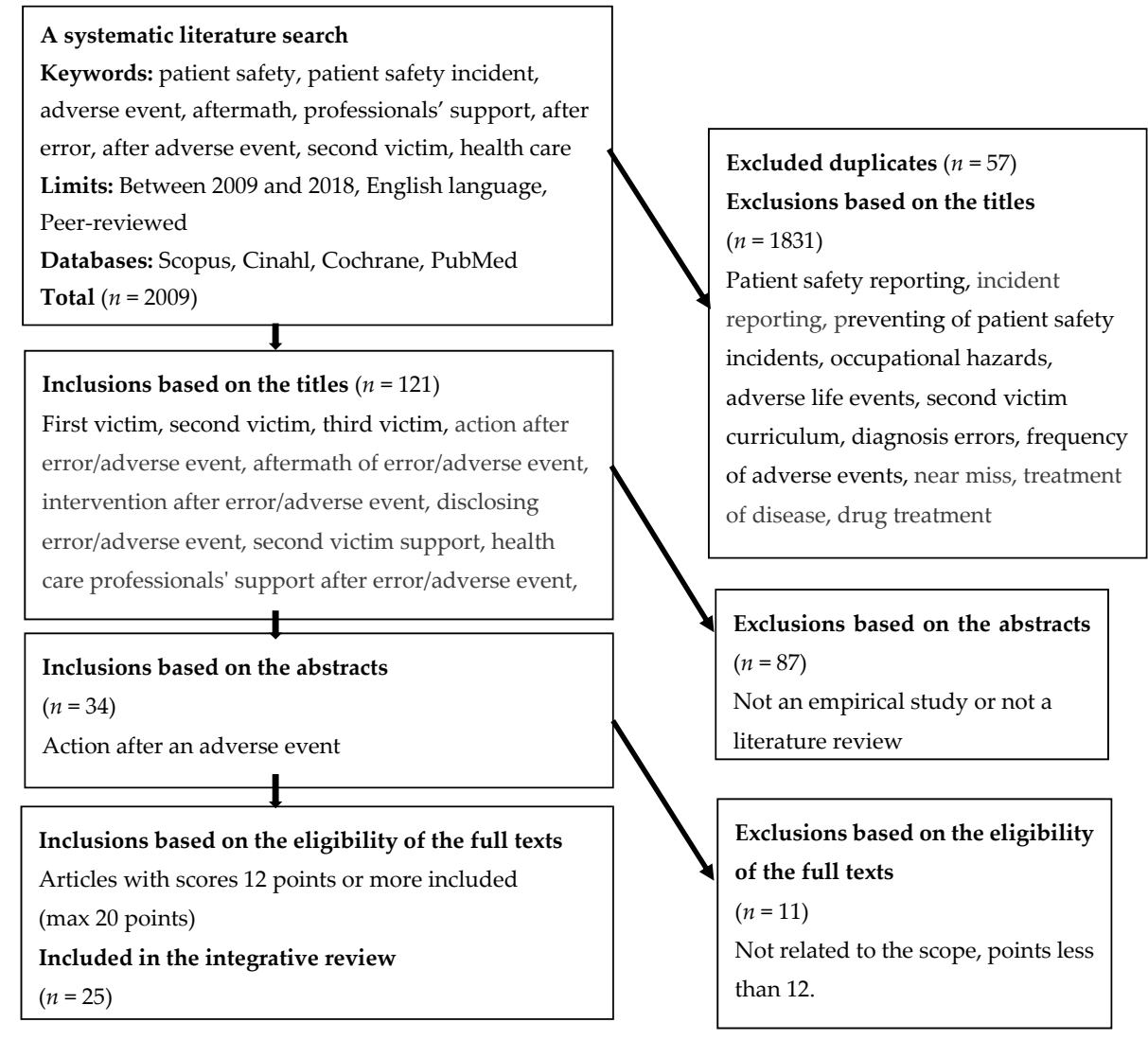

Figure 1. Systematic literature search process regarding action after adverse events. 


\subsection{Review and Quality Assessment Process}

The search process was realised independently by the authors (ML and ST). Online discussions were held with other authors to share results and make decisions on next steps of the process.

The "quality" of papers was evaluated using a tool developed from an amalgamation of previous work [30-33] which was refined via international research group discussions. The evaluation areas included: (1) background; (2) aim and research questions; (3) sample; (4) data collection; (5) data analysis; (6) results; (7) ethical issues; (8) reliability; and (9) usefulness of the results. After discussing relevant evaluation areas for a comprehensive quality assessment, the research group added a further area: (10) strengths and limitations. Each evaluation area was scored from 0 to 2 points using the following criteria: (0) does not meet the aim or lacks data; (1) inaccurate or superficial; and (2) relevant and presented systematically. With 10 evaluation areas and a maximum of 2 points for each area, the range of the scores for a study varied from 0 to 20 points. Anything below 12 points was excluded due to low quality.

The articles retrieved were distributed evenly, and two researchers independently scored each paper using the tool. Total scores for each paper were compared and the content, importance, face validity and quality of each paper discussed. Where differences of three points or more were present, each sub-element score was discussed, and a third research team member acted as a moderator to arrive at a consensus. Cohens' Kappa was calculated to test interrater reliability ( $\kappa=0.83$ ).

\subsection{Data Analysis}

The results of the studies retrieved were analysed using inductive content analysis [34]. First, the studies were read several times and listed in a table to gain an understanding of the whole and the characteristics of the actions taken after an AE. The data reduction phase included extraction of the data into a manageable framework. The aims of the study, research methods, findings, scores and scope of the action after AEs were presented. Then, the data were open coded, abstracted and categorised using content-characteristic words. Sub-categories were developed and discussed in the international research group. Sub-categories were further grouped into categories describing management of action after AEs. Care was taken not to double count data from individual studies duplicated in literature reviews.

\section{Results}

\subsection{Characteristic for the Studies}

The papers retrieved $(n=25)$ were published between 2009 and 2018 (Table 1). The largest numbers of papers were published in $2015(n=5)$ and $2018(n=5)$ and were from the USA $(n=12)$. Various methodologies were present: quantitative $(n=10)$, qualitative $(n=8)$, multiple methods $(n=2)$ and literature reviews $(n=5)$. The quality scores of the papers varied from 12 to 20 points, with a mean of 15.9 and standard deviation 2.1. The majority $(n=21)$ of papers were about second victim phenomenon and less attention was given to first $(n=6)$ and third victim phenomena $(n=4)$. One paper encompassed both first and second victims, three included both second and third "victims" and one paper covered all three "victims". 
Table 1. Studies investigating action after adverse event.

\begin{tabular}{|c|c|c|c|c|}
\hline Author(s) (Year), Country & Purpose and Aims of the Study & $\begin{array}{c}\text { Research Methods/ } \\
\text { Instrument/Sample }(n=25)\end{array}$ & Findings & Evaluation Scores/Scope \\
\hline Scott et al. (2010), USA [12] & $\begin{array}{l}\text { To describe a deployment of an } \\
\text { institutional rapid response system (RRS) } \\
\text { for second victims }\end{array}$ & $\begin{array}{c}\text { Interview and } 10 \text { item web-based survey } \\
\text { Interviews with } 31 \text { healthcare professionals } \\
\text { Survey }(n=898) \text {, medical students, physicians and } \\
\text { professional nurses }\end{array}$ & $\begin{array}{l}\text { Six distinct recovery stages were delineated. } \\
\text { Almost } 40 \% \text { of the respondents had previously heard the term second } \\
\text { victim; } 30 \% \text { have had personal problems within the past } 12 \text { months, such as } \\
\text { anxiety, depression or concerns about their ability to perform their jobs. } \\
\text { Thirty-five per cent of respondents reported receiving support from } \\
\text { colleagues and peers when it was offered and } 29 \% \text { received support from } \\
\text { supervisory personnel. } \\
\text { Eight themes from the narratives to describe general support infrastructure } \\
\text { characteristics to aid second victim recovery were identified. }\end{array}$ & $\begin{array}{c}12.5 \\
\text { Second victim }\end{array}$ \\
\hline Seys et al. (2013a), USA [15] & $\begin{array}{l}\text { To identify supportive interventional } \\
\text { strategies for second victims }\end{array}$ & $\begin{array}{l}\text { Literature review } \\
21 \text { research articles and } 10 \text { non-research articles } \\
\text { Inclusion criteria and search strategy described } \\
\text { PRISMA method was used for reporting }\end{array}$ & $\begin{array}{l}\text { Numerous supportive actions for second victims described in the literature. } \\
\text { Strategies included support organised at the individual, organisational, } \\
\text { national or international levels. Second victim support is needed to care for } \\
\text { healthcare workers and to improve quality of care. Support can be } \\
\text { provided at the individual and organisational levels. } \\
\text { Programs need to include support immediately post adverse event as well } \\
\text { as on a middle- and long-term basis }\end{array}$ & $\begin{array}{c}14 \\
\text { Second victim }\end{array}$ \\
\hline McVeety et al. (2014), Canada [19] & $\begin{array}{l}\text { To analyse and synthesise best evidence } \\
\text { on the perspectives of patients and family } \\
\text { members who encountered adverse } \\
\text { events }\end{array}$ & $\begin{array}{l}\text { Review, } 14 \text { studies that used qualitative } \\
\text { methodologies included } \\
\text { Inclusion criterions and search strategy described, } \\
\text { Joanna Briggs Institute Qualitative Appraisal and } \\
\text { Review Instrument (JBI-QARI) and Appraisal } \\
\text { Checklist for Interpretive and Critical Research }\end{array}$ & $\begin{array}{l}\text { Nine themes were identified relating to patient and family perceptions and } \\
\text { experiences of an adverse event: communication, the disclosure process, } \\
\text { apology, consequences and impact, fear of reprisal and/or interference with } \\
\text { care, learned helplessness, measures of safeguarding, self-discovery and } \\
\text { awareness of errors, and violations of trust. }\end{array}$ & $\begin{array}{c}16 \\
\text { First victim }\end{array}$ \\
\hline Ullström et al. (2014), Sweden [20] & $\begin{array}{l}\text { To investigate how healthcare } \\
\text { professionals are affected by their } \\
\text { involvement in adverse events, with } \\
\text { emphasis on the organisational support } \\
\text { they need and how well the organisation } \\
\text { meets those needs. }\end{array}$ & $\begin{array}{l}\text { Semi-structured interview guide with } 30 \text { questions. } \\
\text { Qualitative content analysis and systematic } \\
\text { classification was used } \\
\text { Healthcare professionals }(n=21)\end{array}$ & $\begin{array}{l}\text { Impact on the healthcare professional was related to the organisation's } \\
\text { response to the event. }\end{array}$ & $\begin{array}{c}15 \\
\text { Second and third victim }\end{array}$ \\
\hline $\begin{array}{l}\text { Kable et al. (2018) } \\
\text { Australia [22] }\end{array}$ & $\begin{array}{l}\text { To understand the effects of adverse } \\
\text { events on nurses in acute health-care } \\
\text { settings. }\end{array}$ & $\begin{array}{l}\text { A qualitative, descriptive study design; } 10 \text { nurses, } \\
\text { semi-structural interview. }\end{array}$ & $\begin{array}{l}\text { Nurses need organisational responses to adverse events, including } \\
\text { collegial support and provision of information after adverse event occur. }\end{array}$ & $\begin{array}{c}17 \\
\text { Second victim. }\end{array}$ \\
\hline $\begin{array}{l}\text { Rodriquez and Scott. (2018) } \\
\text { USA [24] }\end{array}$ & $\begin{array}{l}\text { To examine experiences of healthcare } \\
\text { professionals who changed paths after an } \\
\text { adverse event. }\end{array}$ & $\begin{array}{l}\text { Web-based survey with total of } 105 \text { individual } \\
\text { responded; } 77(73,3 \%) \text { were eligible to complete } \\
\text { the survey. }\end{array}$ & $\begin{array}{l}\text { Healthcare professionals reported a pattern of inadequate social support } \\
\text { after adverse event. More transparency and support to help professionals } \\
\text { recover is needed. }\end{array}$ & $\begin{array}{c}14 \\
\text { Second victim }\end{array}$ \\
\hline Mira et al. (2015a), Spain [25] & $\begin{array}{c}\text { To identify and analyse } \\
\text { organisation-level strategies adopted in } \\
\text { both primary care and hospitals in Spain } \\
\text { To address the impact of serious AE on } \\
\text { second and third victims }\end{array}$ & $\begin{array}{l}\text { A cross-sectional survey study. The questionnaire } \\
\text { explored five intervention areas: safety culture; } \\
\text { health organisation crisis management plans for } \\
\text { serious AE; measures to ensure transparency in } \\
\text { communication with patients (and relatives) who } \\
\text { experience an AE; care and support for } \\
\text { second victims and actions to protect the } \\
\text { reputation of the health organisation (the third } \\
\text { victim). Developed by consensus among the } \\
\text { research team on the basis of reviews } \\
\text { Managers of hospital and primary care centres } \\
(n=197) \text {, patient safety coordinators in hospitals } \\
\text { or primary care }(n=209)\end{array}$ & $\begin{array}{l}\text { Deficient provision of support for second victims was acknowledged by } \\
71 \% \text { and } 61 \% \text { of the participants from hospitals and primary care, } \\
\text { respectively; these respondents reported that there was no support } \\
\text { protocol for second victims in place in their organisations. Regarding third } \\
\text { victim initiatives, } 35 \% \text { of hospital and } 43 \% \text { of primary care professionals } \\
\text { indicated that no crisis management plan for serious AE existed in their } \\
\text { organisation, and, in the case of primary care, there was no crisis } \\
\text { committee in } 34 \% \text { of cases. The degree of implementation of second and } \\
\text { third victim support interventions was perceived to be greater in hospitals } \\
\text { (mean 14.1, SD 3.5) than in primary care (mean 11.8, SD 3.1) }(p<0.001)\end{array}$ & $\begin{array}{c}17.5 \\
\text { Second and third victim }\end{array}$ \\
\hline
\end{tabular}


Table 1. Cont.

\begin{tabular}{|c|c|c|c|c|}
\hline Author(s) (Year), Country & Purpose and Aims of the Study & $\begin{array}{c}\text { Research Methods/ } \\
\text { Instrument/Sample }(n=25)\end{array}$ & Findings & Evaluation Scores/Scope \\
\hline Gu and Itoh (2012), China [35] & $\begin{array}{l}\text { To explore Chinese patients' views on } \\
\text { physician disclosure } \\
\text { actions after an adverse event and their } \\
\text { acceptance of different types of } \\
\text { apologies from the physician who caused } \\
\text { the event. } \\
\end{array}$ & $\begin{array}{l}\text { Questionnaire with seven sections concerning } \\
\text { responding views of issue related to medical errors } \\
\text { and patient safety } \\
\text { Inpatients and families }(n=934)\end{array}$ & $\begin{array}{l}\text { A large difference identified in the level of patient acceptance between a } \\
\text { physician's "full" or "partial" apology. } \\
\text { It is suggested that Chinese hospitals should adopt an "open" policy, } \\
\text { which should include a "sincere" apology to the patient who experienced a } \\
\text { medical error in order to maintain mutual trust between the staff and } \\
\text { patients. }\end{array}$ & $\begin{array}{c}17 \\
\text { First victim }\end{array}$ \\
\hline Mira et al. (2015b), Spain [36] & $\begin{array}{l}\text { To assess the effect of adverse events that } \\
\text { occur in primary care and hospital } \\
\text { settings on health professionals in } \\
\text { personal and professional terms }\end{array}$ & $\begin{array}{l}\text { A cross-sectional study } \\
\text { Online survey, randomly selected sample; } 1087 \\
\text { health professionals completed the questionnaires } \\
\text { (610 from primary care and } 477 \text { from hospitals) }\end{array}$ & $\begin{array}{l}\text { In total, } 430 \text { health professionals had informed a patient of an error. Error } \\
\text { reporting to patients was carried out by those with the strongest safety } \\
\text { culture, under } 5 \text { y years of age and primary care staff. Primary care } n=318) \\
\text { and hospital }(n=346) \text { health professionals reported having gone through } \\
\text { the second-victim experience. The emotional responses were: feelings of } \\
\text { guilt, anxiety, re-living the event, tiredness, insomnia and persistent } \\
\text { feelings of insecurity. In doctors, the most common responses were feelings } \\
\text { of guilt and re-living the event, while nurses showed greater solidarity in } \\
\text { terms of supporting the second victim in both PC and hospital settings. }\end{array}$ & $\begin{array}{c}18 \\
\text { Second victim }\end{array}$ \\
\hline $\begin{array}{l}\text { Sorensen et al. (e-pub 2009), } \\
\text { Australia [37] }\end{array}$ & $\begin{array}{l}\text { To understand patients' and health } \\
\text { professionals' experience of Open } \\
\text { Disclosure and how practice can inform } \\
\text { policy }\end{array}$ & $\begin{array}{l}\text { Semi-structured open-ended interview. Grounded } \\
\text { theory was used to analyse the data } \\
\text { Nurses, managers, policy coordinators, patients } \\
\text { and family members }(n=154)\end{array}$ & $\begin{array}{l}\text { Five major elements influenced patients' and professionals' experiences of } \\
\text { openly disclosing adverse events namely: initiating the disclosure, } \\
\text { apologising for the adverse event, taking the patient's perspective, } \\
\text { communicating the adverse event and being culturally aware. }\end{array}$ & $\begin{array}{c}15.5 \\
\text { First and second victim }\end{array}$ \\
\hline $\begin{array}{l}\text { Koller and Espin (2018) } \\
\text { Canada [38] }\end{array}$ & $\begin{array}{l}\text { To capture perspectives on paediatric } \\
\text { disclosure and identify gaps in } \\
\text { knowledge for best practices and policy } \\
\text { uptake. } \\
\end{array}$ & $\begin{array}{l}\text { Focus group interview with semi-structured } \\
\text { questions; } \\
5 \text { parents, } 14 \text { children and adolescents and } 27 \\
\text { healthcare providers. }\end{array}$ & $\begin{array}{c}\text { Patients and families need full disclosure and right to know about errors. } \\
\text { Health-care professionals need more clarity in policies. Most agreed that a } \\
\text { case-by-case approach was necessary for supporting variations in how } \\
\text { medical errors are disclosed. }\end{array}$ & $\begin{array}{c}19 \\
\text { First victim }\end{array}$ \\
\hline $\begin{array}{l}\text { Hågensen et al. (2018) } \\
\text { Norway [39] }\end{array}$ & $\begin{array}{l}\text { To present patients' perspectives of } \\
\text { disclosure of and healthcare } \\
\text { organisations' response to adverse } \\
\text { events. }\end{array}$ & Qualitative study; 15 in-depth interviews. & $\begin{array}{l}\text { Three main topics regarding patients' experiences of adverse events are: (1) } \\
\text { ignored concerns or signs of complications; (2) lack of responsibility and } \\
\text { error correction; and (3) lack of support, loyalty and learning opportunities. }\end{array}$ & $\begin{array}{c}20 \\
\text { First victim }\end{array}$ \\
\hline Mira et al. (2017), Spain [40] & $\begin{array}{l}\text { To summarise the knowledge about the } \\
\text { aftermath of adverse events and to } \\
\text { develop a recommendation set to reduce } \\
\text { their negative impact in contexts where } \\
\text { there in no previous experience and } \\
\text { apology laws are not present. }\end{array}$ & $\begin{array}{l}\text { Three information sources were used; review } \\
\text { studies }(n=14 \text { publications), institutional websites } \\
\text { (16 websites were reviewed) and experts' opinions } \\
\text { and experience on patient safety (four focus group } \\
\text { sessions with } 27 \text { participants). }\end{array}$ & $\begin{array}{l}\text { Recommendations focused on eight areas: (1) Safety and organisational } \\
\text { policies; (2) Patient care; (3) Proactive approach to preventing reoccurrence; (4) } \\
\text { Supporting the clinician and healthcare team; (5) Activation of resources to } \\
\text { provide an appropriate response; (6) Informing patients and//or family members; (7) } \\
\text { Incident analysis; and (8) Protecting the reputation of health professionals and of } \\
\text { the organisation. }\end{array}$ & $\begin{array}{l}19 \\
\text { First, } \\
\text { Second } \\
\text { and } \\
\text { third victim }\end{array}$ \\
\hline $\begin{array}{l}\text { Treiber et al. (2018) } \\
\text { USA [41] }\end{array}$ & $\begin{array}{l}\text { To discuss the second victim syndrome } \\
\text { and its impacts on nurses. }\end{array}$ & $\begin{array}{l}\text { Online survey with multiple-choice and } \\
\text { open-ended items were sent to } 842 \text { resent nursing } \\
\text { graduates } 168 \text { responses were received. }\end{array}$ & $\begin{array}{l}\text { Fifty-six per cent reported making at least one medication error. After } \\
\text { making a medical error nurses had emotional responses, such as fear and } \\
\text { disappointment. Nurses described often been supported by peers, nursing } \\
\text { manager and preceptors. }\end{array}$ & $\begin{array}{c}12 \\
\text { Second victim }\end{array}$ \\
\hline Burlison et al. (2017), USA [42] & $\begin{array}{l}\text { To present the development and } \\
\text { psychometric } \\
\text { evaluation of the Second Victim } \\
\text { Experience and Support Tool (SVEST), } \\
\text { a survey instrument that can assist } \\
\text { healthcare organisations to implement } \\
\text { and track the performance of second } \\
\text { victim support resources }\end{array}$ & $\begin{array}{l}\text { Quantitative study } \\
\text { Second Victim Experience and Support Tool } \\
\text { (SVEST) questionnaire development, 5-point } \\
\text { Likert scale Nurses, physicians, pharmacists and } \\
\text { medical technicians in specialised paediatric } \\
\text { hospital }(n=305)\end{array}$ & $\begin{array}{l}\text { The SVEST (The Second Victim Experience and Support Tool) can be used } \\
\text { by healthcare organisations to evaluate second victim experiences of the } \\
\text { quality of existing support resources. } \\
\text { Means: Psychological distress 2.6. physical distress } 2.3 \text {, colleague support } \\
\text { 2.2, supervisor support 2.8, institutional support } 2.3, \text { non-work-related } \\
\text { support 2.4, professional efficacy 2.5, turnover intentions 2.1, } \\
\text { absenteeism } 1.8 \\
\text { The most desired second victim option: A discussion with a } \\
\text { respected peer } 81 \% \\
\text { The second most desired option: A discussion with the manager } 74 \%\end{array}$ & $\begin{array}{c}19.5 \\
\text { Second victim }\end{array}$ \\
\hline
\end{tabular}


Table 1. Cont.

\begin{tabular}{|c|c|c|c|c|}
\hline Author(s) (Year), Country & Purpose and Aims of the Study & $\begin{array}{c}\text { Research Methods/ } \\
\text { Instrument/Sample }(n=25)\end{array}$ & Findings & Evaluation Scores/Scope \\
\hline Edrees et al. (2011), USA [43] & $\begin{array}{l}\text { To emphasise the importance of support } \\
\text { structures for second victims in the } \\
\text { handling of patient adverse events and in } \\
\text { building a culture of safety within } \\
\text { hospitals. }\end{array}$ & $\begin{array}{l}\text { A cross-sectional survey using a two-part Second } \\
\text { Victim Questionnaire Nurses, nursing or other } \\
\text { managers, physicians, pharmacists, therapists, } \\
\text { clinical support, technologists }(n=140 \text { in part one } \\
\text { and } n=95 \text { in part two) }\end{array}$ & $\begin{array}{l}\text { There is a need for second victim support strategy in healthcare organisations. } \\
\text { Informal emotional support and peer support are among the most } \\
\text { requested and most useful strategies. Other desired support: Prompt } \\
\text { debriefing, crisis intervention stress management }(75 \%) \text {, an opportunity to } \\
\text { discuss ethical concerns related to an event or process ( }(46 \%) \text {, a safe } \\
\text { opportunity to contribute to the prevention of similar events in the future } \\
(45 \%)\end{array}$ & 13.5 Second victim \\
\hline Ferrús et al. (2016), Spain [44] & $\begin{array}{l}\text { To identify what occurs among healthcare } \\
\text { providers after an adverse event and } \\
\text { what colleagues could do to help them }\end{array}$ & $\begin{array}{l}\text { A qualitative study applying consensus search } \\
\text { techniques } \\
\text { Focus group and metaplan } \\
\text { Physicians }(n=15), \text { nurses }(n=12)\end{array}$ & $\begin{array}{l}\text { Consensus about second victims requiring support from their colleagues } \\
\text { and managers; many times, second victims perceive rejection. They } \\
\text { experience fear, repetitive thoughts and loneliness. Formal information } \\
\text { channels favour implementation of improvements. HCPs perceived that } \\
\text { information on measures for preventing another adverse event is } \\
\text { inaccessible. Managers reported that a change in behaviour is necessary to } \\
\text { improve patient safety culture. Common informal channels included } \\
\text { cafeterias and hallways. Colleagues of second victims' reactions included } \\
\text { surprise and pursuit to avoid involvement. }\end{array}$ & $\begin{array}{c}16 \\
\text { Second victim }\end{array}$ \\
\hline Joesten et al. (2015), USA [45] & $\begin{array}{c}\text { To establish a baseline of perceived } \\
\text { availability of institutional support } \\
\text { services or interventions and experiences } \\
\text { following an adverse patient safety event } \\
\text { (PSE) }\end{array}$ & $\begin{array}{l}\text { Quantitative study, The Medically Induced } \\
\text { Trauma Support Services Staff Support Survey } \\
\text { (MITSS) Nurses }(n=82) \text {, physicians }(n=12)\end{array}$ & $\begin{array}{l}\text { Overall, } 10-30 \% \text { of respondents reported that various support services or } \\
\text { interventions were actively offered. Respondents reported having } \\
\text { experienced several distressing symptoms after PSE, such as worrying } \\
\text { memories }(56 \%) \text { and concerns about lawsuits ( } 37 \% \text { ). Most of them } \\
\text { experienced more support from colleagues than from their manager or } \\
\text { department chair. Less than } 32 \% \text { felt that they could report concerns } \\
\text { without fear of punitive action or retribution. }\end{array}$ & $\begin{array}{c}14 \\
\text { Second victim }\end{array}$ \\
\hline Lewis et al. (2013), USA [46] & $\begin{array}{l}\text { To report the effect of medical errors on } \\
\text { nurses }\end{array}$ & $\begin{array}{l}\text { Integrative literature review } \\
21 \text { articles included } \\
\text { Inclusion criteria and search strategy described } \\
\text { Whittemore and Knafl's methodology used }\end{array}$ & $\begin{array}{l}\text { Characteristics of units were important in nurses' experience of medical } \\
\text { errors. Nurse characteristics were essential, for example, number of } \\
\text { nursing practice years. Veteran nurses were more likely to make } \\
\text { constructive changes. Two interventions were: (1) disclosure of a medical } \\
\text { error to the patient; and (2) support available to the nurse. Responses to } \\
\text { the intervention outcomes were: (1) burnout, including emotional } \\
\text { exhaustion, depersonalisation and low personal accomplishment; (2) moral } \\
\text { distress; (3) intention to leave the profession; and (4) positive constructive } \\
\text { changes after medical errors. }\end{array}$ & $\begin{array}{l}15.5 \\
\text { Second victim }\end{array}$ \\
\hline Davies et al. (2015), UK [47] & $\begin{array}{l}\text { To explore student midwives' perceptions } \\
\text { of what was traumatic for them and how } \\
\text { they were supported after such events }\end{array}$ & $\begin{array}{l}\text { Qualitative descriptive approach, using } \\
\text { semi-structured interviews } \\
\text { Student midwives }(n=11)\end{array}$ & $\begin{array}{l}\text { Five main themes: (1) Students' anxiety about entering the profession } \\
\text { including students being forced to adopt practices that devaluate their } \\
\text { commitment; (2) Existential space between a patient and qualified midtwife } \\
\text { occupied by students, having traumatic tensions in the student role; ( } 3 \text { ) } \\
\text { Emergency events were traumatic with students feeling unprepared and } \\
\text { having too much responsibility; (4) Aftermath of emergency events concerning } \\
\text { the impact of the event on students; and (5) Learring to cope related to the } \\
\text { way student coped with such incidents, as well as other stresses in the role. }\end{array}$ & $\begin{array}{c}13.5 \\
\text { Second victim }\end{array}$ \\
\hline
\end{tabular}


Table 1. Cont

\begin{tabular}{|c|c|c|c|c|}
\hline Author(s) (Year), Country & Purpose and Aims of the Study & $\begin{array}{c}\text { Research Methods/ } \\
\text { Instrument/Sample }(n=25)\end{array}$ & Findings & Evaluation Scores/Scope \\
\hline $\begin{array}{l}\text { Harrison et al. (2015), UK/ } \\
\text { USA [48] }\end{array}$ & $\begin{array}{l}\text { To investigate: (a) the } \\
\text { professional or personal disruption } \\
\text { experienced after making an error; (b) the } \\
\text { emotional response and coping strategies } \\
\text { used; (c) the relationship between } \\
\text { emotions and coping strategy selections; } \\
\text { (d) influential factors in clinicians' } \\
\text { responses; and (e) perceptions of } \\
\text { organisational support }\end{array}$ & $\begin{array}{l}\text { Cross-sectional, cross-country survey, The Health } \\
\text { Professional Experience of Error Questionnaire } \\
\text { (HPEEQ) tool } \\
\text { Nurses }(n=145) \text {, physicians }(n=120)\end{array}$ & $\begin{array}{c}\text { Professional and personal disruption reported as a result of } \\
\text { making an error. } \\
\text { Negative feelings common, but positive feelings like alertness, } \\
\text { determination and attentiveness also identified. } \\
\text { Emotional response and coping strategy selection appeared to differ by } \\
\text { professional group; nurses had stronger negative feelings after an error, but } \\
\text { selection did not differ by perceived harm or location. } \\
\text { Problem-focused coping strategies were favoured. Organisational support } \\
\text { services perceived as helpful, especially peers, but there were } \\
\text { fears over confidentiality. } \\
\text { Factors that influence clinician recovery should be considered in the } \\
\text { provision of comprehensive support programs. }\end{array}$ & $\begin{array}{c}17 \\
\text { Second victim }\end{array}$ \\
\hline Seys et al. (2013b), USA [49] & $\begin{array}{l}\text { To determine definitions of second victim, } \\
\text { research the prevalence and the impact of } \\
\text { adverse event on the second victim and } \\
\text { the coping strategies used }\end{array}$ & $\begin{array}{l}\text { Literature review } \\
32 \text { research articles and } 9 \text { non-research articles } \\
\text { were identified }\end{array}$ & $\begin{array}{l}\text { Second victims' common reactions after adverse events can be emotional, } \\
\text { cognitive and behavioural. The coping strategies used by second victims } \\
\text { have an impact on their patients, colleagues and themselves. Defensive as } \\
\text { well as constructive changes have been reported in practice after adverse } \\
\text { events. It is critical that support networks are in place to protect the patient } \\
\text { and involved healthcare providers when an adverse event occurs. }\end{array}$ & $\begin{array}{c}15 \\
\text { Second victim }\end{array}$ \\
\hline $\begin{array}{l}\text { Edrees and Wu } \\
\quad(2017) \\
\text { USA [50] }\end{array}$ & $\begin{array}{l}\text { To assess the extent of the second victim } \\
\text { problem in acute care hospitals, the } \\
\text { availability of emotional support services } \\
\text { and the need for organisational } \\
\text { support programs. }\end{array}$ & $\begin{array}{l}\text { In-depth semi-structured interviews. Patient safety } \\
\text { representatives }(n=43) \text {. }\end{array}$ & $\begin{array}{l}\text { All participants reported that they are aware of second victim problems. } \\
\text { Almost all agreed that hospitals should have a support program for } \\
\text { second victims. }\end{array}$ & $\begin{array}{l}15,5 \\
\text { Second victim }\end{array}$ \\
\hline $\begin{array}{l}\text { Delacroix (2017), } \\
\quad \text { USA [51] }\end{array}$ & $\begin{array}{l}\text { To discern nurse practitioners' } \\
\text { behaviours, perceptions and coping } \\
\text { mechanisms in response to having made } \\
\text { a medical error }\end{array}$ & $\begin{array}{l}\text { Qualitative study, face-to-face semi-structured } \\
\text { interviews }(n=10) .\end{array}$ & $\begin{array}{l}\text { Four themes emerged from interviews: (1) The paradox of error victimisation, } \\
\text { two subthemes were presented (fear for the patients' welfare and fearing } \\
\text { an uncertain professional future; (2) The primacy of responsibility and } \\
\text { mindfulthess, three subthemes were presented (I am responsible, acute } \\
\text { reactions and mindfulness); (3) Yearning for forgiveness and supportive other, } \\
\text { this theme was categorised in two subthemes (non-supportive just culture } \\
\text { and seeking forgiveness and support); and (4) Coping with a new reality is } \\
\text { context dependent, what was split up to two subthemes (atypical coping and } \\
\text { constructive coping). }\end{array}$ & $\begin{array}{c}15.5 \\
\text { Second victim }\end{array}$ \\
\hline $\begin{array}{l}\text { Van Gerven et al. (2016), } \\
\text { Belgium [52] }\end{array}$ & $\begin{array}{l}\text { To evaluate the prevalence and content of } \\
\text { organisations' support systems for } \\
\text { healthcare professionals sinvolved in an } \\
\text { adverse event. }\end{array}$ & $\begin{array}{l}\text { Quantitative descriptive design } \\
\text { Dutch-speaking hospitals }(n=59)\end{array}$ & $\begin{array}{l}\text { Thirty organisations had a systematic plan to support second victims. } \\
\text { The chief nursing officer was seen as one of the main contact people } \\
\text { when something went wrong. In terms of the quality of the protocols, only } \\
\text { a minority followed part of } \\
\text { the international resources. }\end{array}$ & $\begin{array}{c}16 \\
\text { Second and third victim }\end{array}$ \\
\hline
\end{tabular}




\subsection{Key Elements of Responses and Action after AEs Bulleted Lists Look Like This}

Actions following AEs were comprised of three themes, namely first victims, second victims and third victims, with empathic and ethical communication, support services, complete apology and training and learning as cross-cutting elements.

The theme of action for first victims was comprised of four elements: attention in revealing an $\mathrm{AE}$, communication after AEs, first victim support and complete apology (Table 2). Patients and families [19] and healthcare providers [35,36] alike were often afraid of speaking up. Empathic, ethical and open communication played an important role overall; the quality of the communication seemed to either empower or disempower patients and their families [19,37-39]. In many cases, patients are not informed about AEs [40]. Support for first victims was addressed primarily as a lack or neglect of emotional support [36,39] and compensation support [35]. Apologising was an important element after experiencing an AE [19,34,37,38]. First victims perceived the apology as an integrative process, where the style and the presenter of the apology, whether healthcare provider or organisation, played an important role. Expressing empathy, giving honest information about the AE, taking responsibility and learning from the event were crucial to the apology process.

Table 2. "Action after adverse events" regarding first, second and third victim elements.

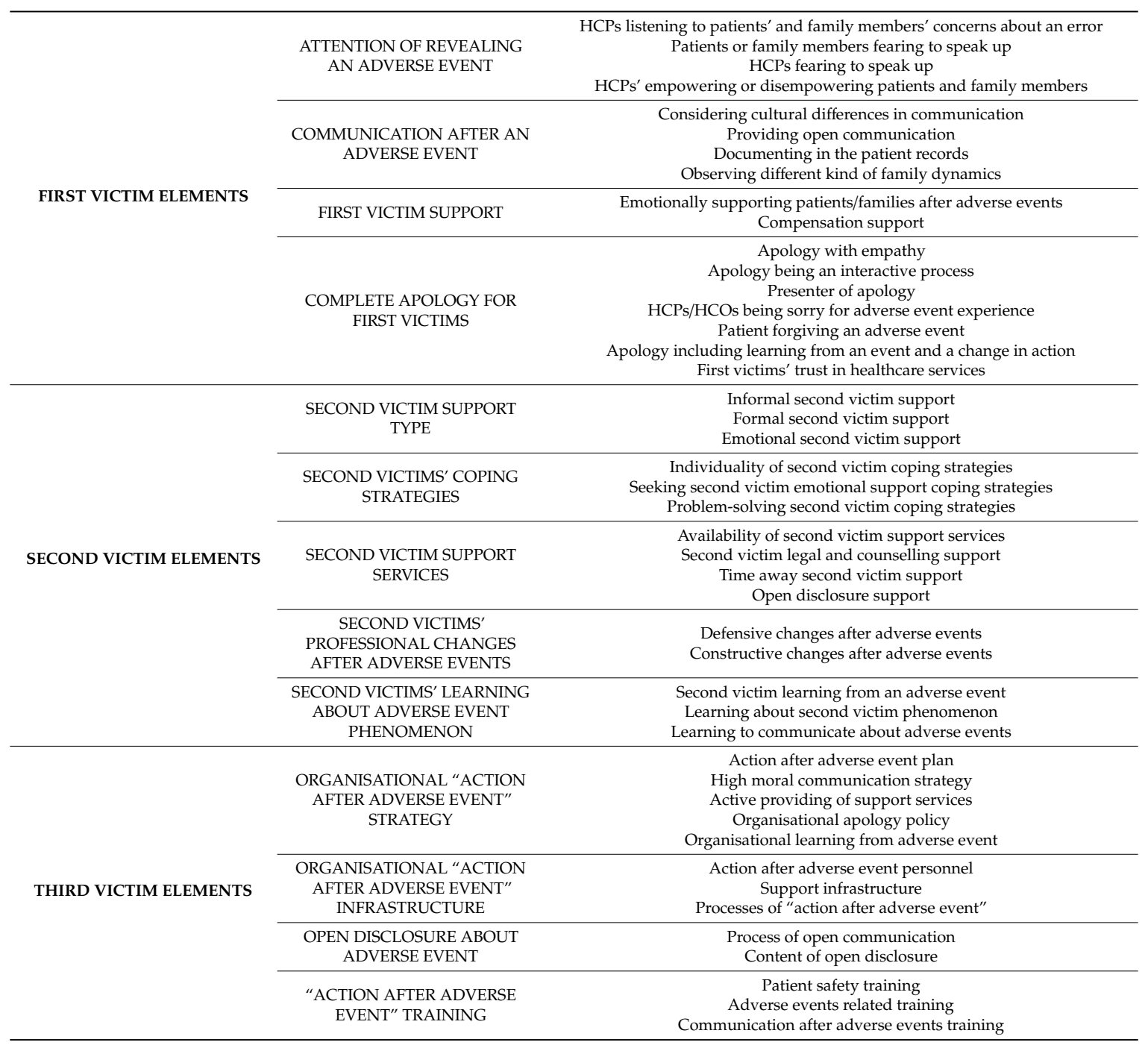

The action for second victims theme consisted of the following elements: second victim support types, coping strategies, support protocols, changes after AEs and learning about AE 
phenomena (Table 2). Support types consisted of informal [12,15,41-45], formal [15,23,25,40,41,46,47] and emotional $[22,42,44-46]$ support for second victims. Healthcare providers have indicated informal peer support as important $[20,41,42,49,50]$, but sensitive. The support can be destroyed, for example, by blaming, gossiping and silence [46]; thus, it is important to pay special attention to non-blaming, open and supportive communication. Formal support was not a certainty and was not offered in all cases $[12,25,42,46,47]$. The importance of emotional second victim support was clear and could be provided for all those involved, for individuals or groups $[43,49,50]$. Second victim coping strategies related to the individuality of strategies [12,49], emotional support $[41,47,49,51]$ and problem solving [47,49].

The second victim support services comprised availability [11,24,25,41,44], counselling support $[36,41,44]$, time away support $[41,44,45]$ and open disclosure support $[37,43,44]$. Changes that second victims make after an $\mathrm{AE}$ can include defensive and constructive changes [50]. It was also found that learning about AEs [47], the second victim phenomenon and learning to communicate about AEs are important for staff members [12,44,48].

The action for the third victims theme consisted of organisational strategy and infrastructure [20,46,49], which was divided into action after adverse events plan [12,25,52], personnel $[36,37,42,46,52]$ and processes $[20,36,52]$ subthemes (Figure 2). The key elements of the subthemes were:

- emphasising open, empathic communication (for example, open disclosure) and each staff member's responsibility for their empowering communication style [25,37,42];

- action after AE support services for first and second victims (for example, emotional support) $[42,44,47,49]$; and

- $\quad$ action after AE training and learning for managers and staff members $[15,19,52]$.

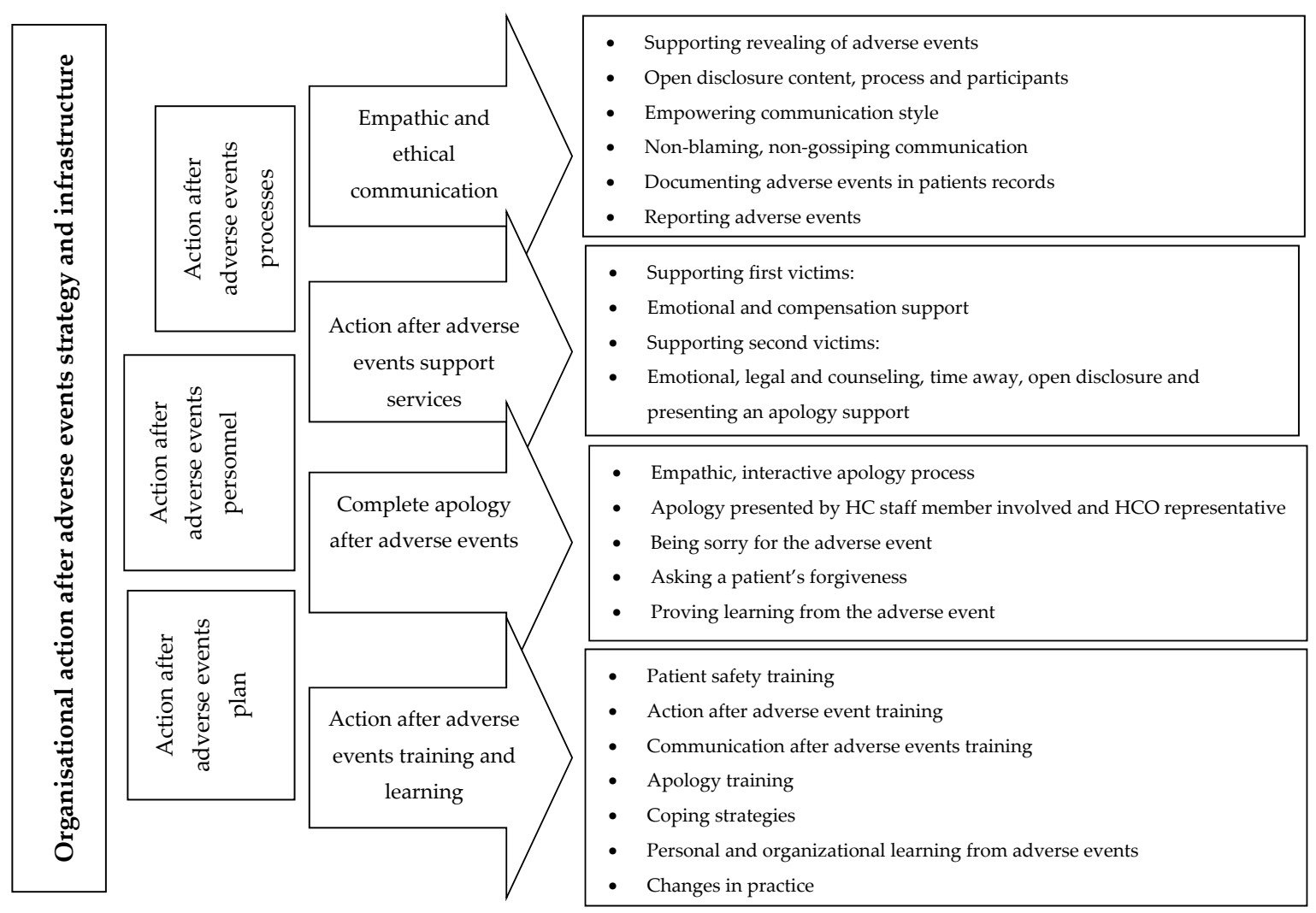

Figure 2. "Action after adverse events" in healthcare organisations. 


\section{Discussion}

The results of this integrative literature review demonstrate how complex and multi-layered the phenomenon "action after $\mathrm{AE}^{\prime}$ is and how this topic has gained attention in international research and healthcare development work. Previous studies have concentrated more on a single perspective regarding actions after AEs, while, in this integrative review, a more holistic view is presented. Key themes emerged relating to victims of AEs: first, second and third victim elements, with empathetic, effective communication, support services, complete apology and training and learning, as cross-cutting elements.

The first victim theme comprised attention to revealing an $\mathrm{AE}$, communication after an event, first victim support and complete apology. The second victim theme included second victim support types, coping strategies, support services, changes after AEs and learning about AE phenomena. The third victim theme consisted of organisational action after AEs, strategy, infrastructure and training and open communication about AEs. These three themes interweave tightly together, and we approach the themes from a healthcare organisation's perspective to outline the needs of first and second victims and how HCOs could respond to these. In this integrative review, second victim support programs were under development work. For example, Scott et al. designed "A Framework of Caring: The Scott Three-Tiered Interventional Model of Support", which features: (Tier 1) unit level support; (Tier 2) trained peer supporters and patient safety and risk management resources; and (Tier 3) an expedited referral network with specialist support [12]. Indeed, a similar kind of support program could also benefit first victims.

Second victim support programs can be assumed to support first victims as well through better preparation of nurses and healthcare providers. However, it could be argued that more comprehensive first victim support programs are also needed. Attention to revealing an AE, open and emphatic communication and complete, authentic apology to, and support of, first victims were essential after AEs. For example, the apology policy of the HCOs seemed to be fragmented and often defensive. First victims highlighted the importance of an empathic, interactive process, where a sincere apology is expressed not just by an individual healthcare provider, but responsibility on the part of the HCO is accepted as well $[53,54]$. First victims implied that in some situations they might forgive, but it was unclear if forgiveness was asked for [35]. Here, an interactive support program could be beneficial for all victims, including nursing and healthcare students. For instance, first victims wanted the apology to include information about how the HCO would learn from the AE and make changes $[19,35]$. First victims had often lost trust in HCOs [19]. Open discussion about what went wrong, and why, can be the first step to understanding and forgiveness [55]. One reason for a loss of trust may be a lack of transparency after AE [56]. First victims should be convinced that everything possible is being done to avoid a similar situation in the future. If the apology included a convince of systematic, organisational level learning from the AE, the professionals involved may feel supported when discussing AEs with patients, peers and managers [57]. From the literature reviewed changes appear needed at the individual, team, unit and organisational levels. The results suggested a need for holistic approaches to managing AEs.

Safe, systematic and clear "action plan after AEs" required an understanding of each stakeholder's needs. AEs consist of complex systems of problems which often interact; thus, it is important to deal with the phenomenon as a whole. Indeed, even those not directly involved may have impact on the consequences of AEs. The strategy and infrastructure of HCOs are crucial to managing action after AEs as part of healthcare delivery. An "action after AE" strategy needs to include a comprehensive plan which attends to the interlinked complexity which often exists. Well-thought-through communication is required from everyone in HCOs: colleagues, managers and second victims as well. AEs are very sensitive events that can have long-term consequences $[12,15,19,20,24]$. Thus, communication is fundamental to occupational and patient safety.

Organisational "action after AEs" infrastructure needed to have appointed personnel, clear support and learning infrastructure and clear processes. It was also important that the process and content 
of open disclosure are included in the management of the events. Emphatic, support and respect by colleagues is needed after AE so that healthcare professionals still feel competent to do their job [20]. With these actions, HCOs may be able to ameliorate the severe consequences for all victims, such as effectiveness of HCOs [12,19,20], economic issues [19] and reputation [19,25]. Nurses and healthcare professionals suffer when involved in AEs, may fear reporting events $[48,58-60]$ and experience difficulties working in an environment where AEs have happened [23]. Being comprehensively prepared is important [58] both to minimise harm to all victims and for the functionality of healthcare systems.

Mira et al. found that many patients are not informed at all about AE. This may be because HCPs are afraid for their professional future, or because they do not have competence to honestly tell a patient what has happened $[38,40,51]$. A shortage of skill and resource lack of competence seems to be one barrier to developing organisational support programs after AE [50]. It is important not to forget the first victims outside this support. It is also good to recognise that first victims have much information about AEs to provide for organisational learning [38,39]. Crucial for this is that action after AE education is included in professional and continuing healthcare programme [33].

The strengths of this study include an international researcher group involved with strong patient safety research, management and education experience. For example, the data evaluation was conducted in two groups. The quality of the research papers was evaluated with an instrument used in an integrative review. Agreement among authors was measured by Cohen's kappa $(\kappa=0.411)$, which can be interpreted as moderate [60]. Limitations include the method itself. Only peer reviewed research papers were used in this review. National or international guidelines and protocols about disclosing adverse events were omitted. The search strategy may have affected the number of different victim phenomena found vary. Combining different methodologies such as qualitative, quantitative and literature reviews can be difficult due to diverse ontological and epistemological underpinnings, which some may view as causing bias [28]. Team discussions regarding key features of the papers were utilised to assist in clarifying the quality of the studies and the main emergent points from each paper. Close attention was also given to the avoidance of double counting in order to avoid "skewing" the findings. The PRISMA statement was used to guide the writing of the review [29].

\section{Conclusions}

It is inevitable that AEs will occur in healthcare organisations, impacting on individual, team, unit, organisation and national levels. When an AE is identified and a concern expressed, immediate and comprehensive action should be taken. This requires trying to understand the whole phenomenon in its complexity, an ambition to manage AEs and a "just restorative" culture [61] that enables it. System-wide developments are needed regarding action after AEs, along with the implementation of evidence-based organisational infrastructures and strategies which could ameliorate the suffering of patients, their families and healthcare providers, as well as help healthcare organisations (and ultimately nations) to use resources effectively. For this developing, more research about patients' and their families' needs as well as organisations' needs is required. Tight collaboration is needed between policy-makers, nursing and healthcare managers and educators in order to develop such systems and the necessary culture [62]. Only then will all victims receive appropriate support after AEs. We also suggest that future education, research, policy and practice developments should incorporate a move to a more balanced approach incorporating both Safety 1 (learning from failure) and Safety 2 (learning from how things typically go right) perspectives [61]. At the national level, social and healthcare ministries are responsible for planning, guidance and implementation of health and social policy to safeguard people's ability to work and function. International collaboration between governments is needed to standardise studies concerning first, second and third victim phenomenon. Governments should build a network of researchers and healthcare managers for developing the study protocols and shared understanding of developing first, second and third victim support system in healthcare organisations. Such a move may assist in the development of "restorative just cultures" in HCOs and more holistic approaches to actions after AEs for the benefit of all "victims". 
Author Contributions: M.L. and S.T. conducted the literature search and evaluation of articles, and were major contributors to the manuscript. A.S., M.F.V.M., P.P., and H.T. participated in evaluation of articles and writing the manuscript. A.M.S.-a. and J.K. took part in manuscript writing. All authors read and approved the final manuscript.

Funding: This research received no external funding.

Acknowledgments: The sixth author would like to thank INVEST Research Flagship funded by the Academy of Finland Flagship Programme (decision number: 320162).

Conflicts of Interest: The authors declare no conflict of interest.

\section{References}

1. Vincent, C. Patient Safety, 2nd ed.; Wiley-Blackwell: Chichester, UK, 2010.

2. Van Gaal, B.G.; Schoonhoven, L.; Mintjes-de Groot, J.A.; Defloor, T.; Habets, H.; Voss, A. Concurrent incidence of adverse events in hospitals and nursing homes. J. Nurs. Sch. 2014, 46, 187-198. [CrossRef]

3. Disclosure Working Group. Canadian Disclosure Guidelines: Being Open and Honest with Patients and Families [Internet]; Canadian Patient Safety Institute: Edmonton, AB, Canada, 2011; Available online: http://www.patientsafetyinstitute.ca/en/toolsResources/disclosure/Documents/CPSI\%20Canadian\% 20Disclosure\%20Guidelines.pdf (accessed on 28 November 2018).

4. World Health Organization. Conceptual Framework for the International Classification for Patient Safety (v.1.1) [Internet]; World Health Organization: Geneva, Switzerland, 2009; Available online: http://www.who.int/ patientsafety/taxonomy/icps_full_report.pdf (accessed on 1 August 2018).

5. De Vries, E.N.; Ramrattan, M.A.; Smorenburg, S.M.; Gouma, D.J.; Boermeester, M.A. The incidence and nature of in-hospital adverse events: A systematic review. BMJ Qual. Saf. 2008, 7, 216-223. [CrossRef] [PubMed]

6. European Commission. Patient Safety and Quality of Care Working Group. Key Findings and Recommendations on Reporting and Learning Systems for Patient Safety Incidents across Europe [Internet]; European Commission: Brussels, Belgium, 2014; Available online: http://ec.europa.eu/health//sites/health/files/patient_safety/docs/ guidelines_psqcwg_reporting_learningsystems_en.pdf (accessed on 1 August 2018).

7. Andersson, Å.; Frank, C.; Willman, A.M.L.; Hansebo, G. Adverse events in nursing: A retrospective study of reports of patient and relative experiences. Int. Nurs. Rev. 2015, 62, 377-385. [CrossRef]

8. Wahlberg, Å.; Sachs, M.A.; Johannesson, K.B.; Hallberg, G.; Jonsson, M.; Skoog Svanberg, A.; Högberg, U. Self-reported exposure to severe events on the labour ward among Swedish midwives and obstetricians: A cross-sectional retrospective study. Int. J. Nurs. Stud. 2017, 65, 8-16. [CrossRef]

9. Donaghy, C.; Doherty, R.; Irwin, T. Patient safety: A culture of openness and supporting staff. Surgery 2018, 36, 09-514. [CrossRef]

10. Edrees, H.; Connors, C.; Paine, L.; Norvell, M.; Taylor, H.; Wu, A.W. Implementing the RISE second victim support programme at the Johns Hopkins Hospital: A case study. BMJ Open 2016, 6, e011708. [CrossRef]

11. Wu, A.W. Medical error: The second victim: The doctor who makes the mistake needs help too. BMJ 2000, 320, 726-727. [CrossRef]

12. Scott, S.D.; Hirschinger, L.E.; Cox, K.R.; McCoig, M.M.; Hahn-Cover, K.; Epperly, K.M.; Epperly, K.M.; Phillips, E.C.; Hall, L.W. Caring for our own: Deploying a systemwide second victim rapid response team. Jt. Comm. J. Qual. Patient Saf. 2010, 36, 233-240. [CrossRef]

13. Hall, L.W.; Scott, S.D. The second victim of adverse health care events. Nurs. Clin. N. Am. 2012, 47, 383-393. [CrossRef] [PubMed]

14. Davidson, J.E.; Agan, D.L.; Chakedis, S.; Skrobik, Y. Workplace blame and related concepts: An analysis of three case studies. Chest 2015, 148, 543-549. [CrossRef] [PubMed]

15. Seys, D.; Wu, A.W.; Van Gerven, E.; Vleugels, A.; Euwema, M.; Panella, M.; Scott, S.D.; Conway, J.; Sermeus, W.; Vanhaecht, K. Health care professionals as second victims after adverse events: A systematic review. Eval. Health Prof. 2013, 36, 135-162. [CrossRef] [PubMed]

16. Mohamadi-Bolbanabad, A.; Morade, G.; Piroozi, B.; Safari, H.; Asadi, H.; Nasseri, K.; Mohammadi, H.; Afkhamzadeh, A. The second victims' experience and related factors among medical staff. Int. J. Workplace Health Manag 2019, 12, 134-145. [CrossRef] 
17. MacLeod, L. "Second victim" casualties and how physician leaders can help. Physician Exec. 2014, 40, 8-12. [PubMed]

18. Conway, J.; Federico, F.; Stewart, K.; Campbell, M. Respectful Management of Serious Clinical Adverse Events, 2nd ed.; [Internet]; IHI Innovation Series White Paper; Institute for Healthcare Improvement: Cambridge, MA, USA, 2011; Available online: http://www.ihi.org/resources/Pages/IHIWhitePapers/ RespectfulManagementSeriousClinicalAEsWhitePaper.aspx (accessed on 23 November 2018).

19. McVeety, J.; Keeping-Burke, L.; Harrison, M.B.; Godfrey, C.; Ross-White, A. Patient and family member perspectives of encountering adverse events in health care: A systematic review. JBI Database Syst. Rev. Implement. Rep. 2014, 12, 315-373. [CrossRef]

20. Ullström, S.; Sachs, M.A.; Hansson, J.; Øvretveit, J.; Brommels, M. Suffering in silence: A qualitative study of second victims of adverse events. BMJ Qual. Saf. 2013, 23, 325-331. [CrossRef]

21. Kable, A.K.; Spigelman, A.D. Why clinicians involved with adverse events need much better support. Int. J. Health Gov. 2018, 23, 312-315. [CrossRef]

22. Kable, A.; Kelly, B.; Adams, J. Effects of adverse events in health care on acute care nurses in an Australian context: A qualitative study. Nurs. Health Sci. 2018, 20, 238-246. [CrossRef]

23. Krzan, K.D.; Merandi, J.; Morvay, S.; Mirtallo, J. Implementation of a "second victim" program in a pediatric hospital. Am. J. Health Syst. Pharm. 2015, 72, 563-567. [CrossRef]

24. Rodriquez, J.; Scott, S.D. When Clinicians Drop Out and Start Over after Adverse Events. Jt. Comm. J. Qual. Patient Saf. 2018, 44, 137-145. [CrossRef]

25. Mira, J.J.; Carrillo, I.; Lorenzo, S.; Ferrús, L.; Silvestre, C.; Pérez-Pérez, P.; Olivera, G.; Iglesias, F.; Zavala, E.; Maderuelo-Fernández, J.; et al. The aftermath of adverse events in Spanish primary care and hospital health professionals. BMC Health Serv. Res. 2015, 15, 151. [CrossRef]

26. Slawomirski, L.; Auraaen, A.; Klazinga, N. The Economic of Patient Safety. Strengthening a Value-Based Approach to Reducing Patient Harm at National Level; OECD: Paris, France, 2017.

27. World Health Organization Regional Office for Europe. Patient Safety, Data and Statistics. Available online: http://www.euro.who.int/en/health-topics/Health-systems/patient-safety/data-and-statistics (accessed on 12 November 2019).

28. Whittemore, R.; Knafl, K. The integrative review: Updated methodology. J. Adv. Nurs. 2005, 52, 546-553. [CrossRef] [PubMed]

29. Moher, D.; Liberati, A.; Tetzlaff, J.; Altman, D.G.; for the PRISMA group. Preferred reporting items for systematic reviews and meta-analyses: The PRISMA statement. BMJ 2009, 339, b2535. [CrossRef]

30. Hawker, S.; Payne, S.; Kerr, C.; Powell, J. Appraising the evidence: Reviewing disparate data systematically. Qual. Health Res. 2002, 12, 1284-1299. [CrossRef]

31. Jokelainen, M.; Turunen, H.; Tossavainen, K.; Jamookeeah, D.; Coco, K. A systematic review of mentoring nursing students in clinical placements. J. Clin. Nurs. 2011, 20, 2854-2867. [CrossRef] [PubMed]

32. Pearson, P.; Steven, A.; Howe, A.; Sheikh, A.; Ashcroft, D.; Smith, P.; on behalf of Patient Safety Education Study Group. Learning about patient safety: Organizational context and culture in the education of health care professionals. J. Health Serv. Res. Policy 2010, 15, 4-10. [CrossRef]

33. Tella, S.; Liukka, M.; Jamookeeah, D.; Smith, N.J.; Partanen, P.; Turunen, H. What do nursing students learn about patient safety? An integrative literature review. J. Nurs. Educ. 2014, 53, 7-13. [CrossRef] [PubMed]

34. Vaismoradi, M.; Turunen, H.; Bondas, T. Content analysis and thematic analysis: Implications for conducting a qualitative descriptive study. Nurs. Health Sci. 2013, 15, 398-405. [CrossRef] [PubMed]

35. Gu, X.; Itoh, K. Patient views and attitudes to physician's actions after medical errors in China. J. Patient Saf. 2012, 8, 153-160. [CrossRef]

36. Mira, J.J.; Lorenzo, S.; Carrillo, I.; Ferrús, L.; Pérez-Pérez, P.; Iglesias, F.; Silvestre, C.; Olivera, G.; Zavala, E.; Nuño-Solinís, R.; et al. on behalf of the Research Group on Second and Third Victims. Interventions in health organisations to reduce the impact of adverse events in second and third victims. BMC Health Serv. Res. 2015, 15, 341. [CrossRef]

37. Sorensen, R.; Iedema, R.; Piper, D.; Manias, E.; Williams, A.; Tuckett, A. Disclosing clinical adverse events to patients: Can practice inform policy? Health Expect. 2010, 13, 148-159. [CrossRef] 
38. Koller, D.; Espin, S. Views of children, parents, and health-care providers on pediatric disclosure of medical errors. J. Child Health Care 2018, 22, 577-590. [CrossRef] [PubMed]

39. Hågensen, G.; Nilsen, G.; Mehus, G.; Henriksen, N. The struggle against perceived negligence. A qualitative study of patients' experiences of adverse events in Norwegian hospitals. BMC Health Serv. Res. 2018, 18, 302. [CrossRef] [PubMed]

40. Mira, J.J.; Lorenzo, S.; Carrillo, I.; Ferrús, L.; Silvestre, C.; Astier, P.; Iglesias-Alonso, F.; Maderuelo-Fernández, J.Á.; Pérez-Pérez, P.; Torijano, M.L.; et al. Lessons learned for reducing the negative impact of adverse events on patients, health professionals and healthcare organizations. Int. J. Qual. Health Care 2017, 29, 450-460. [CrossRef] [PubMed]

41. Treiber, L.A.; Jones, J.H. The second victims of infusion therapy-related medication errors. J. Infus. Nurs. 2018, 41, 156-163. [CrossRef]

42. Burlison, J.D.; Scott, S.D.; Browne, E.K.; Thompson, S.G.; Hoffman, J.M. The Second Victim Experience and Support Tool: Validation of an organizational resource for assessing second victim effects and the quality of support resources. J. Patient Saf. 2017, 13, 93-102. [CrossRef]

43. Edrees, H.H.; Paine, L.A.; Feroli, E.R.; Wu, A.W. Health care workers as second victims of medical errors. Pol. Arch. Intern. Med. 2011, 121, 101-108. [CrossRef]

44. Ferrús, L.; Silvestre, C.; Olivera, G.; Mira, J.J. Qualitative study about the experiences of colleagues of health professionals involved in an adverse event. J. Patient Saf. 2016. [CrossRef]

45. Joesten, L.; Cipparrone, N.; Okuno-Jones, S.; DuBose, E.R. Assessing the perceived level of institutional support for the second victim after a patient safety event. J. Patient Saf. 2015, 11, 73-78. [CrossRef]

46. Lewis, E.J.; Baernholdt, M.; Hamric, A. Nurses' experience of medical errors: An integrative literature review. J. Nurs. Care Qual. 2013, 28, 153-161. [CrossRef]

47. Davies, S.; Coldridge, L. 'No man's land': An exploration of the traumatic experiences of student midwives in practice. Midwifery 2015, 31, 858-864. [CrossRef]

48. Harrison, R.; Lawton, R.; Perlo, J.; Gardner, P.; Armitage, G.; Shapiro, J. Emotion and coping in the aftermath of medical error: A cross-country exploration. J. Patient Saf. 2015, 11, 28-35. [CrossRef] [PubMed]

49. Seys, D.; Scott, S.; Wu, A.; Van Gerven, E.; Vleugels, A.; Euwema, M.; Panella, M.; Conway, J.; Sermeus, W.; Vanhaecht, K. Supporting involved health care professionals (second victims) following an adverse health event: A literature review. Int. J. Nurs. Stud. 2013, 50, 678-687. [CrossRef] [PubMed]

50. Edrees, H.H.; Wu, A.W. Does one size fit all? Assessing the need for organizational second victim support programs. J. Patient Saf. 2017. [CrossRef] [PubMed]

51. Delacroix, S. Exploring the experience of nurse practitioners who have committed medical errors: A phenomenological approach. J. Am. Acad. Nurse Pract. 2017, 29, 403-409. [CrossRef] [PubMed]

52. Van Gerven, E.; Bruyneel, L.; Panella, M.; Euwema, M.; Sermeus, W.; Vanhaecht, K. Psychological impact and recovery after involvement in a patient safety incident: A repeated measures analysis. BMJ Open. 2016. [CrossRef] [PubMed]

53. Kachalia, A.; Bates, D.W. Disclosing medical errors: The view from the USA. Surgeon 2014, $12,64-67$. [CrossRef]

54. Youngson, G.G. Medical error and disclosure-A view from the U.K. Surgeon 2014, 4, 68-72. [CrossRef]

55. Wu, A.W.; McCay, L.; Levinson, W.; Iedema, R.; Wallace, G.; Boyle, D.J.; McDonald, T.B.; Bismark, M.; Kraman, S.S.; Forbes, E.; et al. Disclosing adverse events to patients: International norms and trends. J. Patient Saf. 2017, 13, 43-49. [CrossRef]

56. Frankel, A.; Haraden, C.; Federico, F.; Lenoci-Edwards, J. A Framework for Safe, Reliable and Effective Care; White Paper; Institute for Healthcare Improvement and Safe \& Reliable Healthcare: Cambridge, MA, USA, 2017.

57. Brborovic, O.; Brborvic, H.; Nola, I.A.; Miloševic, M. Culture of blame-An ongoing burden for doctors and patient safety. Int. J. Environ. Res. Public Health 2019, 16, 4826. [CrossRef]

58. Moumtzoglou, A. Factors impeding nurses from reporting adverse events. J. Nurs. Manag. 2010, 18, $542-547$. [CrossRef]

59. Sujan, M. An organisation without a memory: A qualitative study of hospital staff perceptions on reorting and organisational learning for patient safety. Reliab. Eng. Syst. Saf. 2015, 144, 45-52. [CrossRef] 
60. McHugh, M.L. Interrater reliability: The kappa statistic. Biochem. Med. (Zagreb) 2012, 22, 276-282. [CrossRef] [PubMed]

61. Woodward, S. Implementing Patient Safety: Addressing Culture, Conditions and Values to Help People Work Safely; Routledge, Tylor and Francis: New York, NY, USA, 2020.

62. Morrow, J.M.; Gustavson, A.M.; Jones, J. Speaking up behaviours (safety voices) of healthcare workers: A metasynthesis of qualitative research. Int. J. Nurs. Stud. 2016, 64, 42-51. [CrossRef] [PubMed]

(C) 2020 by the authors. Licensee MDPI, Basel, Switzerland. This article is an open access article distributed under the terms and conditions of the Creative Commons Attribution (CC BY) license (http://creativecommons.org/licenses/by/4.0/). 